\title{
УДК [371.315.2/.4:371.321.2/.6]:53:004.032.6
}

Пінчук Ольга Павлівна, молодший науковий співробітник Інституту інформаційних технологій і засобів навчання НАПН України, м. Київ

\section{ПІДВИЩЕННЯ ЕФЕКТИВНОСТІ ПРОЦЕСУ ОПАНУВАННЯ УЧНЯМИ ПОНЯТІЙНОГО АПАРАТУ ФІЗИКИ ЗАСОБАМИ МУЛЬТИМЕДІЙНИХ ТЕХНОЛОГІЙ}

\section{Анотація}

Актуальність матеріалу, викладеного у статті, обумовлена зміною акценту у викладанні навчальних предметів 3 передавання знань на формування здатності та готовності учнів використовувати ці знання у реальних життєвих ситуаціях. У даній статті запропоновано елементи методики формування понятійного апарату учнів на уроках фізики. Описано процес засвоєння учнями системи наукових знань 3 використанням різних методів роботи 3 понятійним апаратом фізики. Залучення засобів мультимедійних технологій розглядається на різних етапах діяльності учителя. Перспективним автор вважає дослідження можливостей поєднання вільного спілкування з аудиторією з використанням комп'ютерної техніки, кооперації засобами мережевих технологій та телекомунікацій 3 навчальною метою.

Ключові слова: навчання фізики, предметна компетентність учнів, понятійний апарат, мультимедійні технології.

Постановка проблеми. Розвиток інноваційних процесів у загальній освіті останніми роками все частіше пов' язують зі зміною акцентів у викладанні навчальних предметів з передавання знань на формування здатності та готовності використовувати ці знання у реальних життєвих ситуаціях. Проблема формування предметної компетентності учнів з фізики залишається актуальною. Ї̈̈ розв'язання, на нашу думку, можливе шляхом вдосконалення, розвитку та ефективної реалізації ідей особистісно орієнтованого навчання, діяльнісного підходу, а також активного використання у навчально-виховному процесі комп'ютерно орієнтованих технічних засобів, які супроводжують життєдіяльність учнів і набули статусу ознаки життєдіяльності сучасної людини.

У дослідженні предметних компетентностей учнів 3 фізики ми виходимо 3 такого: компетентність, у першу чергу, характеризує високу якість навчальних умінь, можливість установлення людиною зв'язків між знаннями та реальною ситуацією, здатність знаходити процедуру, яка допомагає вирішенню проблеми. Компетентність 
базується на створенні великих банків спеціалізованих і систематизованих знань [1]. Фізичні поняття $є$ основою системи наукових знань (Н. А. Мисліцька, I. М. Пустиннікова). Результати проведеного нами аналізу науково-методичних джерел вказують на те, що проблеми формування фізичних понять в учнів загальноосвітньої школи зберігають свою актуальність і набувають нових рис в умовах компетентнісно орієнтованого навчання.

Аналіз останніх досліджень і публікацій. Найбільш загальні теоретичні основи формування фізичних понять обгрунтовано у працях О. І. Бугайова, С. У. Гончаренка, А. В. Касперського, С. В. Коршака, О. І. Ляшенка, М. І. Шута.

Результати сучасних педагогічних досліджень вітчизняних учених підтверджують, що багатоканальність надходження інформації і в той же час цілісність іiі сприйняття сприяють здійсненню вчителем функції роз'яснення [2-5 та ін.]. Посилення наочності на уроках фізики нині - це створення сенсорноперцептивної опори під час сприймання та засвоєння явищ, процесів та подій, що становлять предмет вивчення. Представлення фізичних процесів у динаміці, моделювання умов їх протікання $є$ факторами, що істотно впливають на розуміння та запам' ятовування навчального матеріалу через образне сприйняття та емоційну дію. 3 цією метою вчитель може використовувати відеоролики, анімації, інтерактивні комп'ютерні моделі, фотографії, «презентаційні ряди» PowerPoint, електронні додатки.

Формулювання мети статті. У статті [1] наша увага була зосереджена на обгрунтуванні методики процесу встановлення та поступової активації зв'язків між фізичними поняттями, яка сприяє якісному формуванню моделі предметної області у семантичному просторі суб'єкта навчання, моделі, яка найбільш точно відображає існуючі зв'язки між матеріальними об'єктами фізичної реальності. Успішність розв’язання навчальних та практичних ситуацій різного ступеня складності залежить від ступеня налагодженості зв'язків між елементами моделі предметної області у свідомості учня. Компетентність, як рівень освіченості людини, характеризується здатністю розв' язувати завдання у різних сферах життєдіяльності на базі теоретичних знань. Отже, формування понятійного апарату учнів $\epsilon$ надзвичайно важливим на шляху розвитку їх предметної компетентності. У даній статті нами запропоновано елементи методики процесу встановлення та поступової активації зв’язків між фізичними поняттями у семантичному просторі суб'єкта навчання за допомогою засобів мультимедійних технологій.

Виклад основного матеріалу дослідження. Вихідною формою раціонального пізнання є поняття. Поняття є найбільш широкою і загальною формою мислення, що лежать в основі всього багатства знань, накопиченого людством. Перш ніж 
обговорювати методику засвоєння понятійного апарату фізики, необхідно чітко визначити, що ми розуміємо під цим терміном. Понятійний апарат фізики $\epsilon$ сукупністю понять і категорій предметної області фізики, які утворюють певну систему. Кожне з понять фіксує виділяє та узагальнює об'єкти предметної області за деякою спільною для них і відмінною від інших ознакою [6]. Наприклад, до понятійного апарату фізики входять такі поняття, як «енергія», «маса», «заряд» та ін.

Саме у формі понять відбувається процес засвоєння учнями системи наукових знань. На відміну від життєвих, наукові поняття мають високий ступінь абстрактності. Якщо у процесі навчання зв'язок понять з реальною дійсністю не розкритий, засвоєні поняття стають формальними, не пов’язаними з практикою, а, отже, не впливають на розвиток предметної компетентності учнів. Життєві поняття, які базуються на особистісному досвіді учнів та характеризуються несистематичністю та неусвідомленістю, протягом навчання повинні бути доповнені науковими поняттями. Навчання супроводжується переглядом відомих понять, їх уточненням та переосмисленням. Наукові поняття мають різний ступінь спільності, сферу свого використання. Одні поняття застосовуються лише в межах даної частинної науки, інші ж виявляють тенденцію проникнення у цикл наук, у кожній з яких однаково успішно використовуються. Скажімо, поняття «атом» $є$ спільним для наук фізико-хімічного циклу. Робота над поняттями є важливою частиною навчання фізики. Без їх знання недоцільними є розмови про ефективність і результативність навчального процесу.

Засвоєння понятійного апарату як цілісної системи передбачає встановлення відношень між поняттями за допомогою означень, порівнянь, узагальнень, систематизації. Зв’язки і відношення між об'єктами предметної області носять найрізноманітніший характер: між двома окремими об'єктами, між об'єктом i їх групою, між групами тощо. Різноманіття таких реальних зв'язків і відношень знаходить своє відображення у різноманітті суджень (властивості, процеси). Зміст понять розкривають за допомогою означень.

У курсі фізики переважна більшість фізичних понять спочатку фіксується у вербальній формі, тобто за допомогою словесного конструкта, який побудовано відповідно до законів формальної логіки і сформульовано звичайною мовою. На наступному кроці словесний конструкт деяких фізичних понять дублюється низкою математичних конструктів, за допомогою яких реалізується математичний модельний опис певних характеристик та властивостей фізичної реальності. Математичний конструкт, яким фіксують фізичне поняття, безпосередньо чи опосередковано пов'язаний 3 результатами вимірювань. Формування вербального та формальноматематичного поняття одного і того самого об’єкта фізичної реальності може 
відбуватися у різні роки навчання. Наприклад, поняття «сила Ампера» (9-і і 11-і класи), «напруженість електричного поля» (9-і і 11-і класи), «вільні коливання» (8-і і 11-і класи). Отже, учнями поступово засвоюється вербальний та формальноматематичний понятійний апарат фізики.

У нашому дослідженні були використані різні методи роботи з понятійним апаратом фізики. Серед них: сумісний пошук, порівняння, самостійна робота.

Сумісний пошук. Шляхом логічних розмірковувань учитель разом з учнями формулюють означення поняття, що розглядається. Цей процес може відбуватися так:

1) учитель записує термін на дошці (назву розглядуваного поняття);

2) учні пропонують різні слова, які, на їхню думку, визначають це поняття, учитель фіксує окремі слова і словосполучення на дошці;

3) колективно виділяють 3 переліку ті, без яких не може існувати поняття;

4) виділенні ознаки учитель синтезує в означення.

Метод сумісного пошуку передбачає високу пізнавальну активність учнів протягом уроку, розвиток їх логічного мислення. Проте даний метод може виявитися складним для вчителя, оскільки вимагає жорсткого контролю за процесом створення означення, умілого керування класом.

Самостійна робота. Учням пропонується самостійно визначити нові поняття шляхом вивчення різних джерел інформації. Прикладами понять, які пропонуються для самостійного опанування, $є$ поняття, які вимагають окремих уточнень або систематизації.

Порівняння. Зміст поняття визначається шляхом порівняння декількох понять. Найчастіше використовують цей метод, якщо існує необхідність запобігти плутанині у близьких за значенням поняттях.

У питаннях підвищення якості навчально-виховної роботи вагому роль відіграє ефективне комплексне використання різноманітних засобів навчання. Нові мережеві технології, Інтернет та сучасна проекційна техніка, яка створена на базі інтерактивних мультимедійних технологій, поступово закріплюють свої позиції як елементи освітнього середовища загальноосвітніх навчальних закладів.

Нами створена методика формування предметної компетентності учнів основної школи 3 використанням засобів мультимедійних технологій у процесі навчання фізики. На різних етапах діяльності вчителя (підготовчий, навчальний, оцінювальний) можуть бути залучені апаратні та програмні засоби мультимедійних технологій, мультимедійні навчальні продукти [7].

На підготовчому етапі відповідно до дидактичних принципів навчання та психолого-педагогічних вимог учителем здійснюється відбір та систематизація 
навчальної інформації. Учитель виділяє перелік фізичних понять, які повинні бути включені до семантичного простору учнів певного року навчання під час опанування конкретної навчальної теми (розділу) і відповідають вимогам освітнього стандарту та навчальним програмам; також виділяє зв'язки між поняттями різних категорій. Учитель підбирає систему вправ на встановлення зв'язків між знаннями та ситуаціями, що виникають у реальному житті. Діяльність учителя включає: створення банку схем, означень, формул; відбір демонстраційного матеріалу (малюнки, фотографії, відеофрагменти, анімації тощо). Екранна інформація може мати статичний або динамічний характер. Екранна статична інформація $є$ фіксацією основних понять та зв'язків між ними статичного характеру (стан, властивості). Ефективно використовується як на навчальному, так і на оцінювальному етапі діяльності учителя, збагачуючи «комунікативне поле» [8] навчального процесу. Інтерактивні комп'ютерні моделі, інтерактивні слайд-шоу, фрагменти з демонстрацією зв’язків між фізичними поняттями динамічного характеру (процеси, явища, події) визначають екранну динамічну інформацію. Використання такого типу інформації частіше за все здійснюється на навчальному етапі як за прямого, так і опосередкованого характеру суб' єкт - суб' єктних відношень у комунікативному полі.

Навчальний процес, метою якого $є$ формування предметної компетентності учнів, передбачає не тільки пізнавальну активність учнів, але й зустрічну активність учителя, який перетворює знання в систему способів діяльності і завдань. Проявом такої активності може бути сайт учителя.

Наш аналіз сайтів учителів фізики, розміщених в Інтернеті, показує, що метою створення переважної більшості сайтів є налагодження активної взаємодії учителя 3 колегами: обговорення питань викладання фізики, використання IКT на уроках, проблемні питання сучасності, матеріал для позакласної роботи з учнями. Якщо колекція методичних розробок учителя поповнюється корисними посиланнями на освітні сайти, фотоальбомами, колекціями малюнків, анімацій, моделей, схем, текстових файлів навчальної літератури, матеріалом енциклопедичного характеру, а також зразками тестів, контрольних робіт та вправами поточних домашніх завдань, тоді сайт активно відвідується учнями і виконує роль не тільки гносеологічного компонента методичної системи. Сайт учителя може бути засобом проектування діяльності вчителя, виконувати мотиваційні та організаційні функції відносно самостійної діяльності учня. У традиційній педагогічній взаємодії з'являються нові можливості забезпечити в позаурочний час «глибоку комунікацію на близький дистанції» [8] суб' єктів навчання.

Інтернет орієнтовані ресурси (соціальні пошукові системи, засоби збереження 
закладок, соціальні сервіси збереження мультимедійних ресурсів, карти знань та мережеві щоденники, довідники, електронні посібники, енциклопедії тощо) та мультимедійні електронні видання $\epsilon$ неконтрольованими 3 боку вчителя як організатора навчального процесу. Використовуються на навчальному етапі переважно для здійснення учнями самостійного відбору й упорядкування навчального матеріалу.

Серед понять предметної області фізики важливе місце займають фізичні явища. Для пояснення фізичного явища необхідно акцентувати увагу учнів на зовнішні ознаки плину даного явища та умови, за яких воно відбувається; на зв’язок даного явища 3 іншими, а також на фізичні величини, які його характеризують. Сутність поняття фізичної величини визначають: властивість, яку характеризує дана фізична величина; iii дефініція; формула, яка покладена в основу означення; зв'язок 3 іншими величинами; одиниці фізичної величини, способи їі вимірювання.

У процесі пояснень ми використовуємо динамічні схеми, принцип побудови яких стандартизований і використовується протягом усього навчання. Використання інтерактивних симуляцій фізичних явищ здійснюється на різних етапах формування понятійного апарату учнів, на різних етапах уроку. Учні можуть спостерігати за процесами, які відбуваються у мікросвіті, аналізувати їх причини та наслідки, а, отже, більш ефективно оволодівати змістом фізичних понять.

Для ілюстрації вище зазначеного розглянемо окремі етапи формування поняття «питома теплота пароутворення». На рис. 1 представлено презентаційний ряд, який було використано під час вивчення учнями 8-го класу цього поняття.

КІЛЬКІСТЬ ТЕПЛОТИ. Випаровування i конденсація

Зміна агрегатного стану

твердий рідкий газоподібний
КІЛЬКІСТЬ ТЕПЛОТИ. Випаровування і конденсація

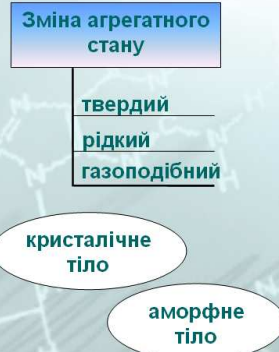




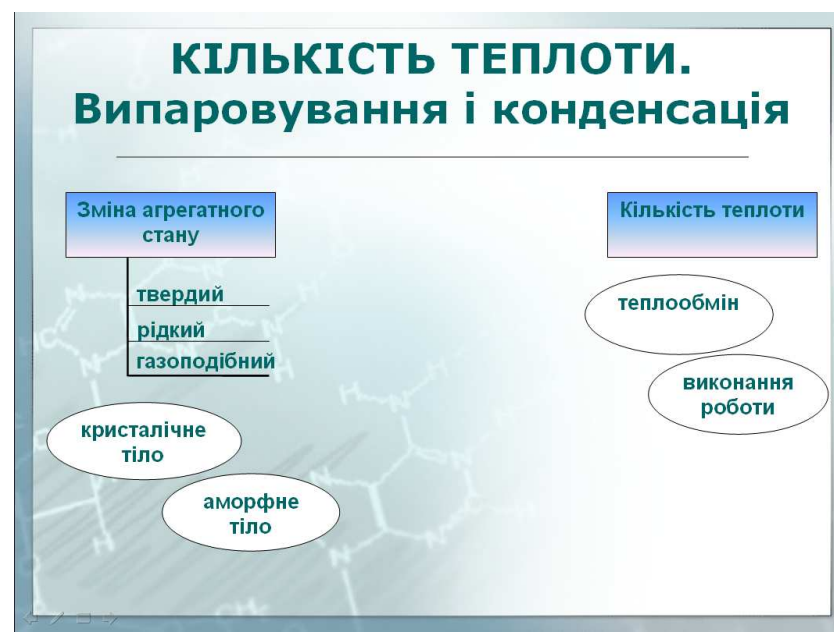

\section{КІЛЬКІСТЬ ТЕПЛОТИ. Випаровування і конденсація}

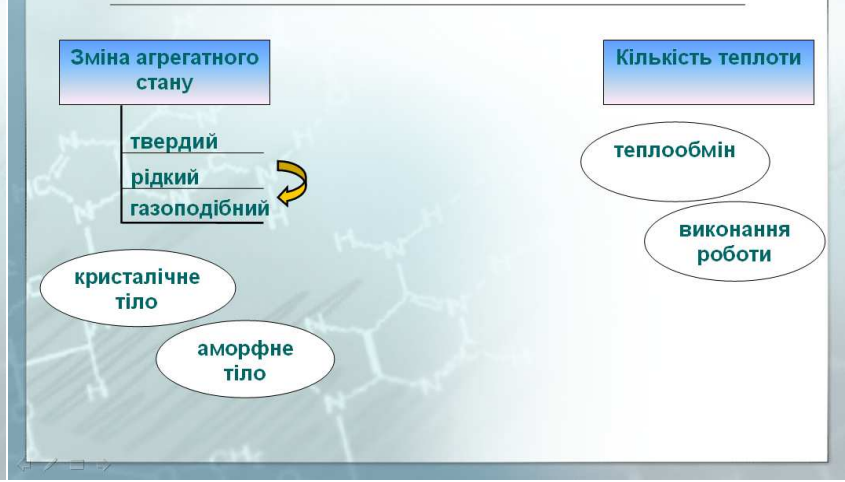

КІЛЬКІСТЬ ТЕПЛОТИ.

Випаровування і конденсація

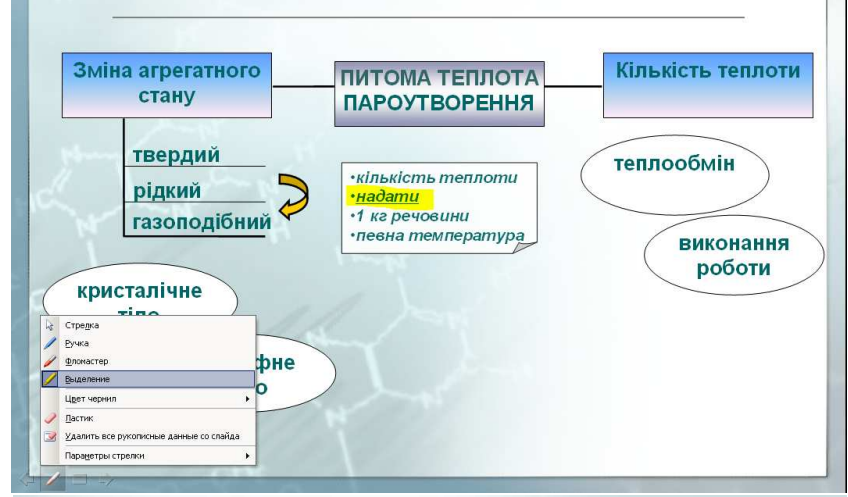

КІЛЬКІСТЬ ТЕПЛОТИ.

\section{Випаровування і конденсація}

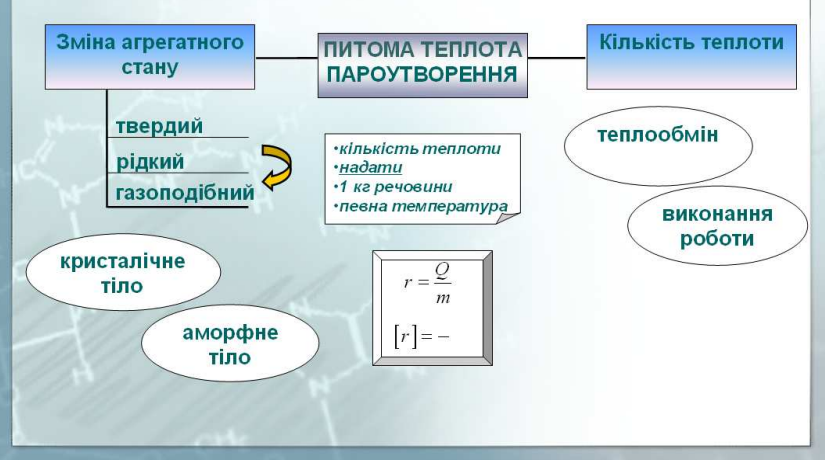

КІЛЬКІСТЬ ТЕПЛОТИ. Випаровування і конденсація

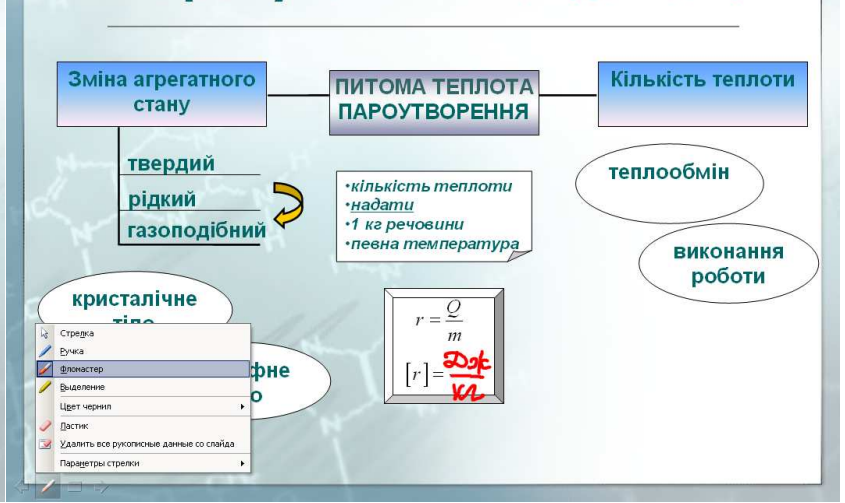

КІЛЬКІСТЬ ТЕПЛОТИ. Випаровування і конденсація

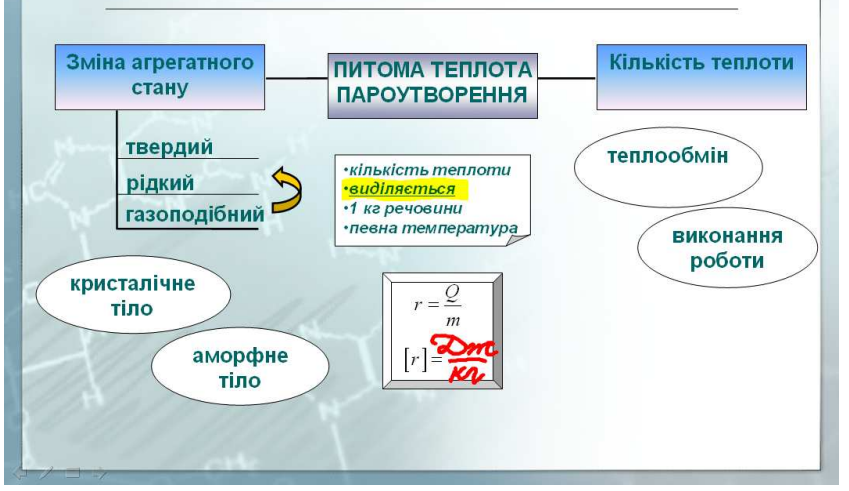


Рис. 1. Презентаційний ряд «Кількість теплоти. Випаровування і конденсація»

Поняття «питома теплота пароутворення» семантично пов'язане 3 поняттям «випаровування», яке визначає явище переходу рідин у газоподібний стан, і поняттям «кількість теплоти», оскільки питома теплота пароутворення характеризує енергетичні витрати на випаровування рідин. Тому на схемах ми розташовуємо поняття «зміна агрегатного стану», «питома теплота пароутворення» та «кількість теплоти» на одній горизонталі й використовуємо однакові фігури для їх позначення (прямокутники). Означуване поняття розташоване посередині. На схемі присутні підпорядковані назви агрегатних станів речовини (твердий, рідкий газоподібний) та стрілка, яка вказує на актуальний (розглядуваний на даному етапі уроку) процес переходу 3 одного агрегатного стану в інший. Цю стрілку доречно зробити активною так, щоб у разі зміни напряму або місця розташування змінювалося означуване поняття і заголовок слайду. Наприклад, «тверде тіло $\rightarrow$ рідина» відповідає поняттю «питома теплота плавлення» заголовку «Кількість теплоти. Плавлення і кристалізація речовини».

У прямокутнику із загнутим кутом ми розміщуємо слова, необхідні для грамотного формулювання означення. Формула виділена багетною рамкою. Одиниці фізичної величини учням запропоновано записати самостійно. У наших схемах еліпси використовуємо для нагадування семантично близьких до розглядуваних понять, значення яких учні повинні розуміти, відтворювати усно та використовувати під час розв'язування задач та поясненнях і обгрунтуванні.

Такий принцип побудови схем 3 метою формування фізичних понять $\epsilon$ ефективним і використовується протягом усього навчання. Наприклад, поняття питома теплота плавлення (рис. 2), питома теплоємність (рис. 3), питома теплота згоряння палива (рис. 4) тощо.

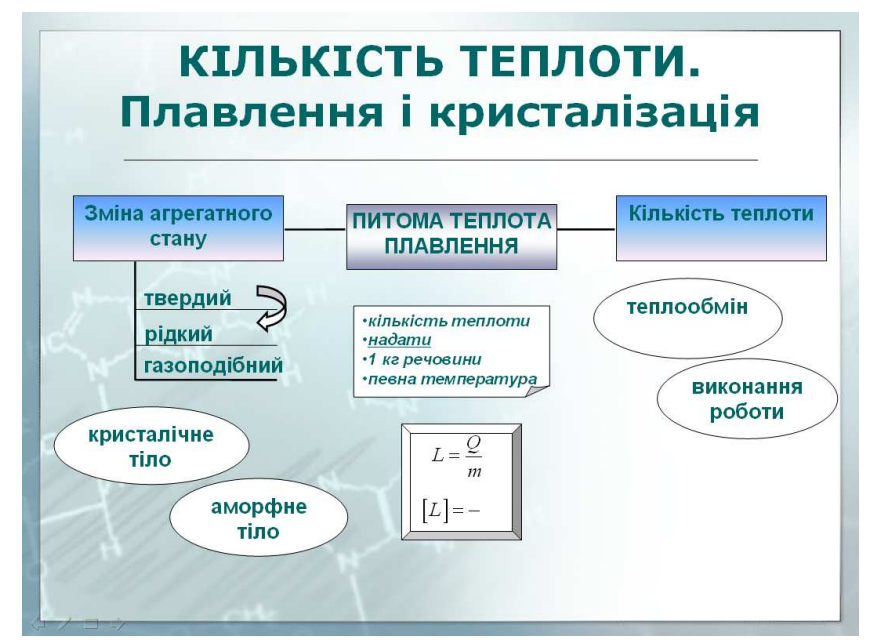

Рис. 2. Слайд «Кількість теплоти. Плавлення і кристалізація» 


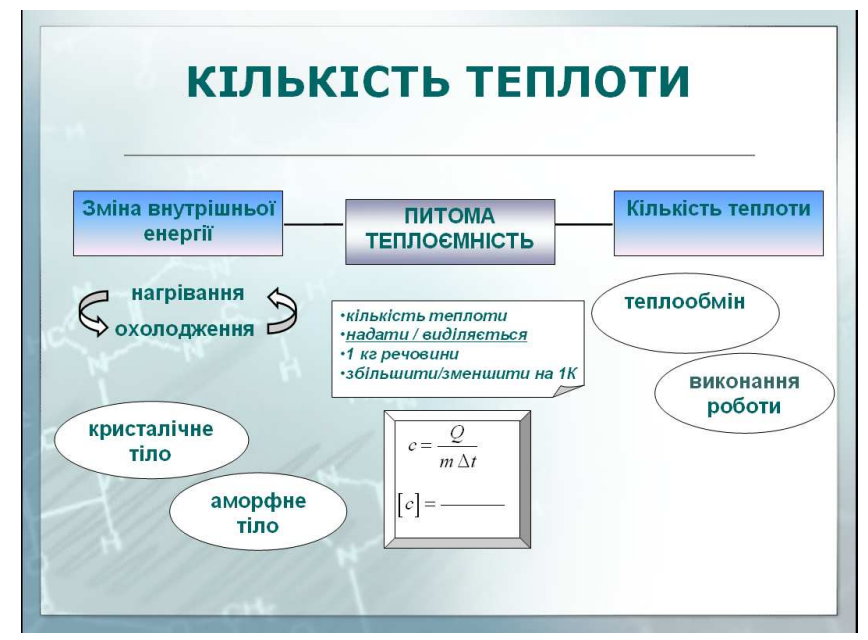

Рис. 3. Слайд «Кількість теплоти»

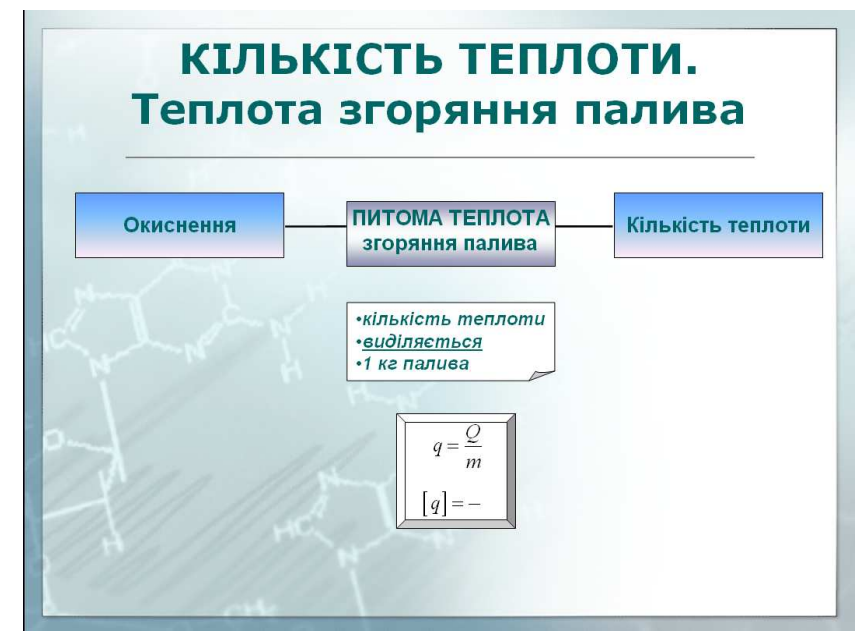

Рис. 4. Слайд «Кількість теплоти. Теплота згоряння палива»

На рис. 5 розміщено екранний образ інтерактивної комп’ютерної моделі «Стан речовини», яка може використовуватися на різних етапах уроку: актуалізації опорних понять, поясненні нового матеріалу, закріплення або на етапі контролю. Модель дозволяє змінювати речовину (неон, аргон, кисень, вода), стан (тверде тіло, рідина, газ) та температуру. Використовуючи закладку «Фазові перетворення», можна досліджувати залежність між тиском, температурою та об’ємом, будувати відповідні графіки. 


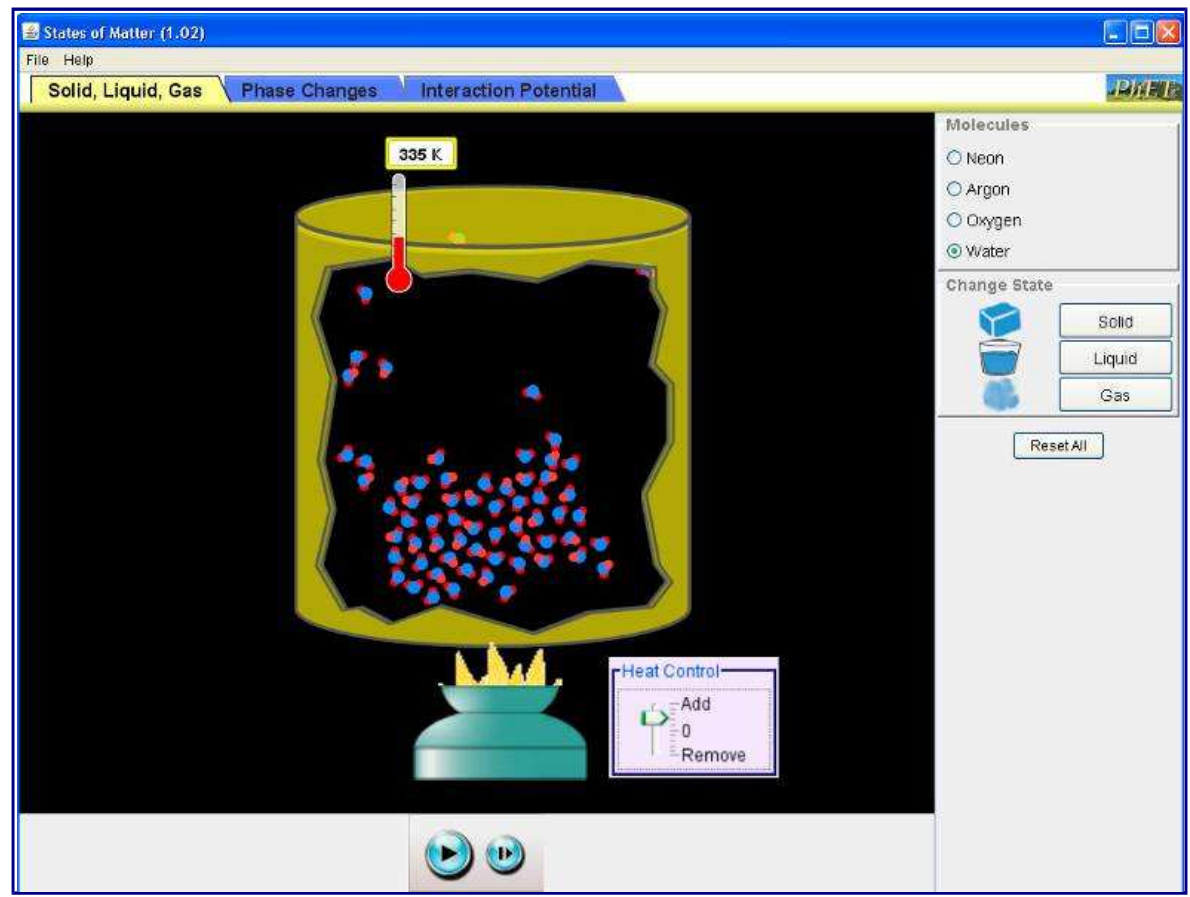

Рис. 5. Комп'ютерна модель «Стан речовини»

Відео «3D робота двигуна внутрішнього згоряння» (рис. 6) може бути використана учителем на навчальному етапі для пояснення перетворення енергії в теплових процесах та принципу дії двигуна внутрішнього згоряння. Це саме відео можна використати на оцінювальному етапі, якщо запропонувати учням самостійно описати принцип дії ДВЗ.

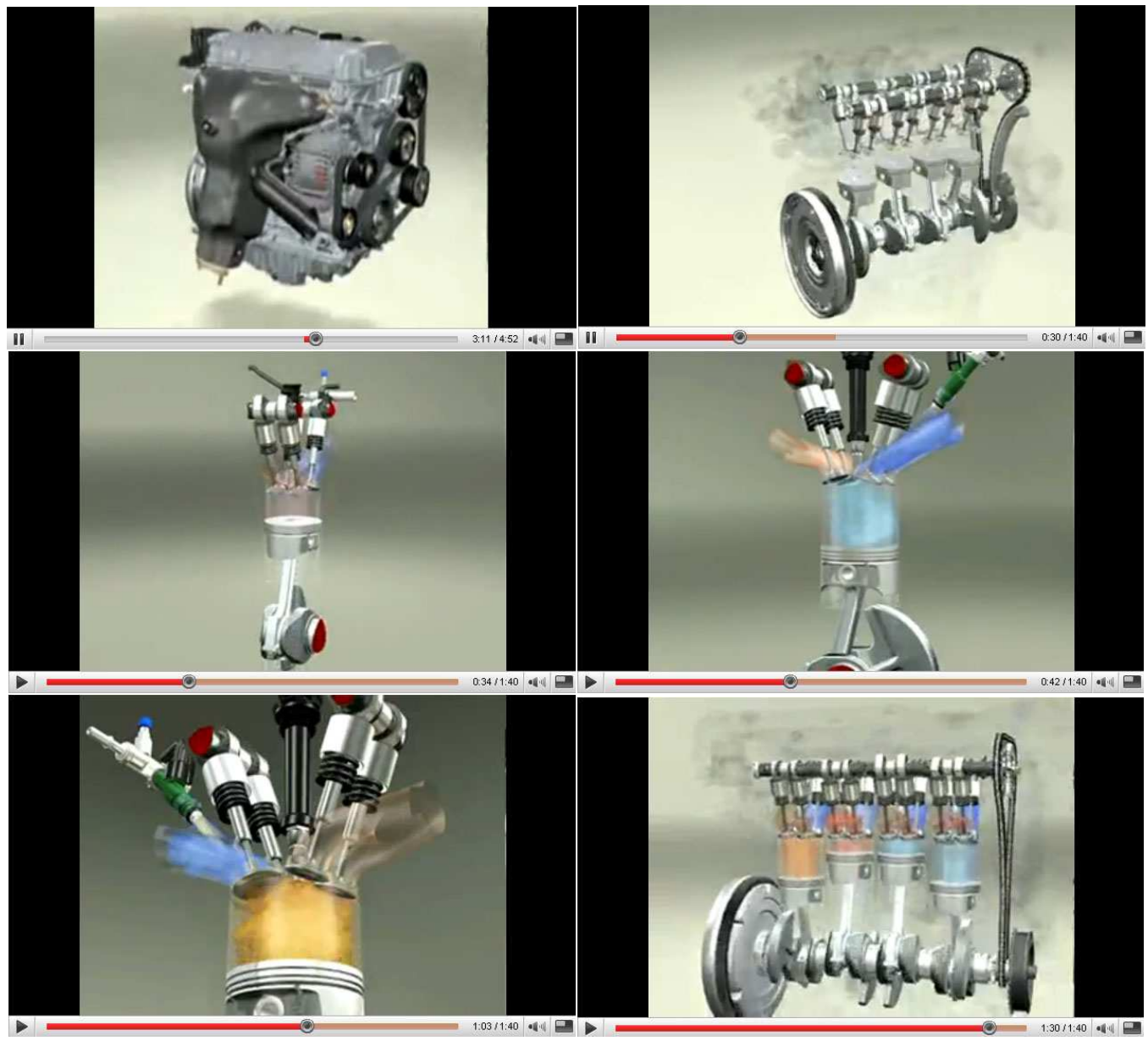


Рис. 6. Анімація «Двигун внутрішнього згоряння»

Отже, учні протягом уроку можуть спостерігати за процесами, які відбуваються у мікросвіті, аналізувати їх причини та наслідки; слідкувати за роботою механізмів, аналізувати їх будову, а, отже, оволодівати змістом навчання фізики більш ефективно.

Висновки. У комп'ютерно орієнтованому навчальному середовищі загальноосвітньої школи учитель отримує додатковий інструмент для активного та ефективного впливу на опанування учнями понятійного апарату фізики. Проте, корисність засобів мультимедійних технологій цим не вичерпується. Швидка зручна обробка та передавання інформації протягом уроку; поєднання вільного спілкування 3 аудиторією (фронтальні та групові види комунікації) з використанням комп'ютерної техніки; перспектива співробітництва та кооперації засобами мережевих технологій та телекомунікацій - створюють хороші перспективи для формування вміння учнів коротко та чітко формулювати думки, аргументовано доводити свою точку зору, поважати думку партнера. На нашу думку, виховання в учнів толерантності, здатності вести дискусію $є$ перспективним напрямом педагогічних досліджень застосування у навчально-виховному процесі мультимедійних технологій.

\section{Список використаних джерел}

1. Пінчук О. П. Вдосконалення моделі предметної області в індивідуальній свідомості учнів як необхідна умова розвитку їх предметної компетентності / О. П. Пінчук // Наукові записки (пед. науки). - Кіровоград: РВВ КДПУ ім. В. Винниченка. - 2009. - Вип. 82. - Частина 1. - С. 80 - 84.

2. Благодаренко Л. Ю. Підвищення педагогічної ефективності навчання фізики в основній школі під час використання мультимедійних технологій [Електронний ресурс] / Л. Ю. Благодаренко // Збірник наукових праць Бердянського державного педагогічного університету. - 2009. - №3. - Режим доступу до електронного видання: http://www.nbuv.gov.ua/portal/soc_gum/znpbdpu/Ped/2009_3/Blagodarenko\%20L..pdf.

3. Заболотний В. Ф. Унаочнення в процесі вивчення фізики за допомогою електронного посібника / В. Ф. Заболотний, Б. А. Сусь, Н. А. Мисліцька // Матеріали II Всеукраїнської науково-практичної конференції «Сучасні тенденції розвитку інформаційних технологій в науці, освіті та економіці». - Луганськ: Вісник Східноукраїнського національного університету, 2008.

4. МисліцькаН.А. Формування фізичних понять в учнів основної школи засобами інформаційних технологій навчання: Автореф. дис. ... канд. пед. наук: 13.00.02 / Наталія Анатоліївна Мисліцька ; НПУ ім. М. П. Драгоманова. - Київ, 2007. $20 \mathrm{c}$.

5. Мисловська С. К. Методика використання електронних додатків до 
підручників фізики в основній школ : Автореф. дис. ... канд. пед. наук : 13.00.02 / Світлана Костянтинівна Мисловська ; НПУ ім. М. П. Драгоманова. - Київ, 2007. -20 c.

6. Понятие [Електронний ресурс] // Российская педагогическая энциклопедия.

Более 2000 терминов. - $\quad$ [2010]. http://www.otrok.ru/teach/enc/index.php?n=16\&f=97. - Заголовок з екрана.

7. Пінчук О. П. Проблема визначення мультимедіа в освіті: технологічний аспект / О. П. Пінчук // Нові технології навчання: наук.-метод. зб. / [Кол. авт.]. - К.: Інститут інноваційних технологій і змісту освіти, 2007. - Вип.46. - С. 55-58.

8. Пінчук О. П. Результати експериментальних досліджень застосування мультимедійних технологій в навчальному процесі базової школи / О. П. Пінчук // Проблеми освіти: наук. зб. / [Кол. авт.]. - К.: Інститут інноваційних технологій і змісту освіти МОН України, 2008. - Вип. 55. - С. 41-50.

\section{ПОВЫШЕНИЕ ЭФФЕКТИВНОСТИ ПРОЦЕССА ОВЛАДЕНИЯ УЧЕНИКАМИ ПОНЯТИЙНОГО АППАРАТА ФИЗИКИ СРЕДСТВАМИ МУЛЬТИМЕДИЙНЫХ ТЕХНОЛОГИЙ}

Пинчук О. П.

\section{Аннотация}

Актуальность материала, изложенного в статье, обусловлена изменением акцента в преподавании учебных дисциплин с передачи знаний на формирование способности и готовности учащихся применять эти знания в реальной жизни. В статье предложены элементы методики формирования понятийного аппарата учащихся на уроках физики. Описан процесс овладения учениками системы научных знаний с использованием различных методов работы с понятийным аппаратом физики. Привлечение средств мультимедийных технологий рассматривается на разных этапах деятельности учителя. Исследование возможности объединить свободное общение с аудиторией и использование компьютерной техники, кооперировать средства сетевых технологий и коммуникаций в учебных целях автор рассматривает как перспективное.

Ключевые слова: обучение физике, предметная компетентность учащихся, понятийный аппарат, мультимедийные технологии.

\section{EFFICIENCY INCREASE OF MASTERING PROCESS OF PHYSICS CONCEPTUAL APPARATUS BY STUDENTS THOUGHT THE INSTRUMENTALITY OF MULTIMEDIA FACILITIES}

Pinchuk $O$.

Resume 
The relevance of the article material specified the change of accent in school subjects teaching from the transmission of knowledge to forming of students' ability and willingness to use this knowledge in the real vital situations. The elements of forming method of students' conceptual apparatus on the lessons of physics are offered. The process of mastering of scientific knowledge system by students with the use of different working methods with conceptual apparatus of physics is described. Use of multimedia technologies on the different stages of teacher's activity is studied. The author considers research of possibilities of combination of the free communication with an audience with the use of computer device and co-operation of means of network technologies and telecommunications with an educational purpose to be perspective.

Keywords: studies of physics, students' subject competence, conceptual apparatus, multimedia technologies. 